\title{
AN ANNOTATED BIBLIOGRAPHY OF PORTO RICAN CANE INSECTS:
}

By E. Gratwood Sartin.

(1) 1880. Stahl, A.

La Enfermedad de la Caña de Azúcar en Puerto Rico, 1880.

(2) 1882. Stahl, A.

Fauna de Puerto Rico. Clasificación sistemática de los Animales que Corresponden a Esta Fauna y Catálogo dei Gabinete Zoológico del Doctor A. Stahl en Bayamón, Puerto Rico. Imprenta del "Boletín Mercantil," 37 Calle de la Fortaleza, San Juan, 1882, pp. 249.

Insectos, pp. 169-213. Lists Sphenophorus sericeus Latr. (= Metamasius hemipterus Linn.), Laphygma frugiperda S. \& A., and Gryllotalpa hexadactyla (E Scapteriscus vicinus Seud.).

(3) 1884. Umpierre, Manuel Fernández.

Distintas Causas que Perjudican a la Caña Durante su Existencia, pp. 70-76. In Manual Práctico de la Agricultura de la Caña de Azúcar, Puerto Rico. Imprenta del Boletín Mercantil, calle de la Fortaleza, Núm. 37, San Juan, 1884, pp. 199.

Mentions grass-worms, moth stalk-borer and mealybug.

(4) 1886. BaLY, J. S.

Descriptions of Uncharacterized Species of Diabrotica. In Trans. Ent. Soc., London, 1886. Part IV (December, 1886), pp. $443-445$.

From P. R., Diabrotica graminea sp. n., p. 443.

(5) 1886. QUEDENFELT, E.

Neuse und seltnere Kafer von Portorico. In Berliner Entomolog. Zeitschrift, pp. 119-128.

(6) 1887. Gundlach, Juan.

Fauna Pnerto-Riqueña. Anales de la Sociedad Española de Historia Natural, Tomo XVI, Cuad. 1, Madrid, Alcalá 11, 31 de mayo de 1887.

Insectos, pp. 347-658.

(7) 1889. Kruger, Dr. W.

Das Zuckerrohr und seine Kultur, p. 312.

Records Delphax saccharivora Westw.

(8) 1895. Tuero, Fernando López.

Enemigos de la Caña y Modo de Combatirlos, Capítulo IV, pp. 63-74. Enfermedad de la Caña de Azúcar, pp. 105-123. In La Caña de Azúcar en Puerto Rico, su Cul-

* References are arranged chronologically, but alphabetically under each year. Anony. mous articles are indicated by dashes. 
tivo y Enfermedad. Tipografía de "Boletín Mercantil," calle de la Fortaleza 24, San Juan, 1895.

Under "Clasificación del Insecto," pp. 114-115, discusses "el caculo" as belonging to genus Leucothyros and including 5 species, his descriptions of which seem to include Phyllophaga, Dyscinetus and Ligyrus. Figures (Lámina 2) the egg, larva, pupa and adult of Phyllophaga sp.

(9) 1900. Busck, A.

Notes on a Brief Trip to Puerto Rico in January and February, 1899. In U. S. D. A., Bu. Ent., Bul. 22 (n. s.), 1900 , pp. 88-92.

Mentions Diatrea saccharalis, Sphenophorus sexguttatus Drury, a lemellicorn larva, and Dactylopius sacchari as cane pests, and discusses the changa as a tobacco pest.

(10) 1900. Pergande, T. and Cockereld, T. D. A.

List of Coccidæ Collected by Mr. A. Busck in Puerto Rico, 1899. In U. S. D. A., Bu. Ent., Bul. 22 (n. s.), 1900, pp. $92-93$.

Lists Dactylopius sacchari Ckll, from three localities on cane.

(11) 1901. GARDNER, F. D.

Ann. Rept., P. R. Agr. Expt. Sta., U S. D. A., for 1901 (Ann. Rept. Office Expt. Stations, Washington, June 30, 1901), pp. 381-415.

Scapteriscus didactylus, p. 414.

(12) 1901.

Notes from Correspondence. In U. S. D. A., Bu. Ent., Bul. 30 (n. s.), pp. 97-98.

Diaprepes abbreviatus sent in by J. W. Van Leenhoff from Porto Rico.

(13) 1902. BARRETT, O. W.

The Changa or Mole-Cricket (Scapteriscus didactylus Latr.) in Porto Rico. Bul. 2, P. R. Agr. Expt. Sta., U. S. D. A., Mayagüez, Sept. 13, 1902, pp. 19, fig. 1.

Dealt with as pest of "tobaceo, cane, and small crops."

(14) 1903. Fernald. Mrs. M. E.

Catalogue of the Coccidæ of the World. Bul. 88, Hatch

Expt. Sta., Mass. Agr. College, Mar. 1903, pp. 360.

Lists Pseudococcus sacchari (Ckll.) on sugar cane from Porto Rico (p. 109).

(1.5) 1903. GARDNer, F. D.

Annual Rept. of the P. R. Agricultural Experiment Station for 1902. In Ann. Rept., Office Exp. Stations for June 30, 1902, Washington, 1903, pp. 331-357.

Discusses may-beetle and larva (p. 343) and gives 
extract of Bul. 2 of same station, dealing with changat (pp. 343-352).

(16) 1904. BaRRETT, O. W.

Control of the Brown Ant (Solenopsis germinata Fabr.) in

Orange Orchards. Cir. 4, P. R. Agr. Expt. Sta., U. S. D. A., May 9, 1904, pp. 3.

Discussed as a citrus pest. Mentions Lachnosterna sp. (p. 3).

(17) 1904. BARRETT, O. W.

Report of O. W. Barrett, Entomologist and Botanist. In Ann. Rept., P. R. Agr. Exp. Sta. for 1903 (Ann. Rept. Office Exp. Stations, June 30, 1903), Washington, 1904, pp. 429-450.

Discusses white ants (Eutermes morio?) (pp. 442443), changa (pp. 443-447), Exophthalmus spengleri (p. 446) and the larva of a weevil (apparently sphenophorus) (p. 448).

(18) 1904. EarLe, F. S.

Report on Observations in Porto Rico. In Ann. Rept., P. R. Agr. Exp. Sta., U. S. D. A., for 1903 (Ann. Rept. Office Exp. Stations, June 30, 1903), Washington, 1904, pp. 454-468.

Note on Lachnosterna sp. (p. 459) and a small ant, presumably Solenopsis, injuring orange trees.

(19) 1905. BaRRETT, O. W.

Report of the Entomologist and Botanist. In Ann. Rept., P. R. Agr. Exp. Sta., U. S. D. A. for 1904 (Ann. Rept. Office Expt. Stations, June 30, 1904), Washington, 1905, pp. 387-399.

Discusses Solenopsis germinata on citrus (p. 388), also the changa, the termite (Eutermes morio), the weevil (Exophthalmus spengleri) and 4 Lamellicorm beetles (p. 396).

(20) 1905. Kelloga, Vernon L.

American Insects, New York, Henry Holt and Company, 1905, pp. 694, plates.

Scapteriscus didaclylus in Porto Rico, p. 161.

(21) $1905 . V_{A N}$ LeEnhoff, J., JR.

Tobaceo Investigations in Porto Rico during 1903-4. Bul. 5, P. R. Agr. Exp. Sta., U. S. D. A., Mayagüez, 1905, pp. 47.

Note on control of changa, p. 13.

(22) 1906. Cook, Melvilue $\mathrm{T}$.

Informe del Departamento de Patología Vegetal. In Primer Informe Anual, Estación Central Agronómica de Cuba, Apr. 1, 1904, to June 30, 1905, Habana, 1906, pp. 147-207.

Note on damage of changa in P. R., p. 1.98. 
(23) 1906. Evans, W. H.

Exhibitions and notes, p. 22 . In Proc. Hawaiian Ent. Soc., I (1905), Apr. 3, 1906, p. 22.

Mentions the fire flies (Pyrophorus) and Scapteris. cus didactylus Latr. in Porto Rico.

(24) 1906. Henricksen, H. C.

Report of the Horticulturist. In Rept. on Agr. Investigations in P. R., 1905 (Bul. 171, Office Exp. Stations, U. S. D. A., 1906), pp. 23-41.

Notes May-beetle (pp. 24-28), brown ant (p. 28 ) and Exophthalmus spengleri (p. 27) among citrus pests.

(25) 1906. MAY, D. W.

(Report of Special Agent in Charge.) In Rept. on Agr. Investigations in P. R., 1905 (Bul. 171, Office Exp. Stations, U. S. D. A., 1906), pp. 1-21.

Mentions Diatrca saccharalis Fab. damaging cane.

(26) 1907. Tower, W. V.

Report of the Entomologist and Plant Pathologist. Im Ann. Rept., P. R. Agr. Exp. Sta. for 1906, Mayagüez Apr. 18, 1907, pp. 25-28.

Notes the May-beetle and leaf-weevil, Diaprepes spengleri (p. 26), among citrus pests, and Diatrcea saccharalis (p. 28) as damaging cane.

(27) 1908. MaY, D. W.

Summary of Investigations. In Arn. Rept., P. R. Agr. Exp. Sta. for 1907, Mayagüez, Nay 4, 1908, pp. 1-15.

Mentions changa and ants (p.10) in relation to cane planting.

(28) 1908. Tower, W. V.

Control of the Brown Ant (Solenopsis germinata Fabr.) and the Mealy Bug (Pseudococcus citri Risso) in Pineapple Plantations. Circ. 7, P. R. Agr. Exp. Sta., U. S. D. A., Mayagüez, 1908.

(29) 1908. Tower, W. V.

Report of the Entomologist and Plant Pathologist. In Ann. Rept. P. R. Agr. Exp. Sta. for 1907, Mayagüez, May 4, 1908, pp. 31-38.

Diseusses Diaprepes (p. 31) and Lachnosterna (p. 32) as citrus pests, changa (p. 39) as tobacco pest and mealy bugs (p. 36), Sphenophorus sp. and Xyleborus sp. (p. 37) as cane pests.

(30) 1908. WHEELER, Dr. WM. M.

The Ants of Porto Rico and the Virgin Islands. Bui. Am. Mus. of Nat. Hist, Vol. 24, Feb. 7, 1908, pp. 117-158, pls. 2.

(31) 1909. Kirkaldy, G. W.

A Bibliography of Sugar-Cane Entomology. Exp. Sta. 
H. S. P. A., Div. of Ent., Bul. 8, Honolulu, Dec. 24 . 1909, pp. 73.

Lists various publications and articles dealing with P. R. cane pests.

(32) 1909. RHen, James A. G.

A Catholog of the Orthoptera of Cuba and the Isle of Pines. In Second Report, Part 2, Estación Central Agronómica de Cuba, Habana, 1909, pp. 175-226.

Records Scapteriscus didactylus Latr. (p. 217) and Orocharis vaginalis Sans. (p. 225) as occurring in Porto Rico.

(33) 1909. Tower, W. V.

Report of the Entomologist. In Ann. Rept. P. R. Agr. Exp. Sta. for 1908, Mayagüiez, Sept., 1909, pp. 23-28.

Notes Diaprepes and May beetle (p. 25) as citrus pests.

(34) 1910. Max, D. W.

Sugar Cane in Porto Rico. In Bul. 9, P. R. Agr. Exp. Sta., U. S. D. A., Mayagüez, Apr. 1910, pp. 44.

Mentions the changa and the white grub as important cane pests, p. 44.

(35) 1910. Moore, E. L.

Insect Pests and Their Extermination. In The Porto Rice Horticultural News, San Juan, Sept. 1910, pp. 134, 143144.

Discusses the changa, p. 143.

(36) 1910. Tower, W. V.

Report of the Entomologist. In Ann. Rept. P. R. Agr. Exp. Sta. for 1909, Mayagüez, Sept., 1910, pp. 24-28. 25).

(37) 1911. JoHnston, J. R.

First Rept. of the Pathologist. In Bul. 1, Exp. Sta., P. R. S. P. A., Río Piedras, 1911, pp. 35-48.

Mentions white grub and root diseases (pp. 36-37), root diseases and flies (p. 39), red rot and borers ( $p$. 45), and toprot and moth borer (p. 47).

(38) 1911. Tower, W. V.

Report of the Entomologist. In Ann. Rept., P. R. Agr. Exp. Sta. for 1910, Mayagüez, July 17, 1911, pp. 31-34.

Discusses cane insects of Cuba compared with those of Porto Rico, pp. 33-34.

(39) 1911. Tower, W. V.

Insects Injurious to Citrus Fruits and Methods for Combatting Them. Bul. 10, P. R. Agr. Exp. Sta., U. S. D. A., Mayagüez, May 8,1911 , pp. 35 , pls. 5.

Deals with Diaprepes spengleri (p. 8), Lachnosterna 
sp. (p. 10), and Solenopsis geminata (p. 11), among citrus pests.

(40) 1911. VAN Ding, D. L.

First Report of the Entomologist. Bul. 1, Exp. Station,

P. R. Sugar Growers' Assn., Río Piedras, 1911, pp. $17-31$.

Discusses at length Diatrcea saccharalis Fab. (pp. 19-22), Lachnosterna sp. (pp. 22-27), changa (pp. 27-29), Pseudococcus sacchari (p. 29) and Metamasius hemipterus (pp. 29-30).

(41) 1911. VAN DINE, D. L.

The Sugar-Cane Insects of Hawaii. U. S. D. A., Bu. Ent., Bul. 93, June 15, 1911, pp. 54, pls. 4, figs. 5.

Notes Sphenophorus sexguttatus Drury (p. 36) (=Melamasius hemipterus Linn,) and Scapteriscus didactylus (p. 45) as occurring in Porto Rico.

(42) 1912. Holloway, T. E.

Insects Liable to Dissemination in Shipments of Sugar Cane. U. S. D. A., Bu. Ent., Cir. 165, Dec. 27, 1912, pp. 8.

Notes Pseudococcus sacchari (Ckll.) and Scapteriscus didactylus Latr.(p. 5) from Porto Rico.

(43) 1912. Hooker, Chas. W.

The Ichneumon Flies of America belonging to the tribe Ophionini. Trans. Am. Ent. Soc., Vol. 38, Nos. 1-2, June 12, 1912.

From Porto Rico: Ophion bilineatus Say (p. 45) and Ophiopterus forrugineus Cress. (pp. 176b-176c, addenda), enemies of cutworms and grass worms.

(44) 1912. JoHNSTON, JoHN R.

Report of the Pathologist. In 2nd Ann. Rept., Exp. Sta.,

P. R. S. P. A., for 1911-1912, Río Piedras, 1912, pp. $23-28$.

Discusses work on fungus control of cane insects (p. 27).

(45) 1912. VAN DINE, D. L.

Damage to Sugar-Cane Juice by the Moth Stalk-Borer (Diatrcea saccharalis Fabr.). Cir. 1, Exp. Sta., P. R. S. P. A., Río Piedras, 1912, pp. 11.

(46) 1912. VAN Dine, D. L.

Progress Rept. on Introductions of Beneficial Parasites into P. R. In 1st Rept. Bd. of Comm. Agr. of P. R., period from July 1, 1911 to Jan., 1912, pp. 31-47.

Discusses insect (Tiphia and Pyrgota) and fungus (Metarrizium) enemies of May-beetles, and the ladybeetle (Cryptolcemus) enemy of mealy-bugs.

(47) 1912. VAN Dine, D. L.

Rept. of the Entomologist (2d. Rept.). In 2nd Ann. 
Rept., Expt. Sta., Sugar Producers' Assn. of P. R., for 1911-12, Río Piedras, 1912, pp. 15-22.

Reports on cane pests, especially moth borer, Maybeetle, mealybug and "leaf-hopper" (Delphax saccharivora Westw.).

(48) 1912. WALTON, W. R.

A New Species of Tachinida from Porto Rico. In Proceedings Ent. Soc. of Washington, vol. XIV, No. 4, Jan. 10, 1912, pp. 198-200, pl. X.

Description of Cryptomeigenia aurifacies n. sp., reared from the "sugar cane May-beetle."

(49) 1913. Ballow, H. A.

Root Borers and Other Grubs in West Indian Soils. In Agricultural News, Barbados, for Mar. 29 (pp. 106107), Apr. 12 (p. 122), Apr. 26 (pp. 138-1391, May 10 (pp. 154-155). May 24 (pp. 170-171) and June 7, 1913 (p. 186; table).

Includes discussions of known Porto Rican species.

(50) 1913. Baliou, H. A.

Root Borers and Other Grubs in West Indian Soils. Pamphlet Series No. 73, Imp. Dept. Agr. for W. I., Barbados, 1913, pp. 38, figs. 21.

Reprint of preceding, with illustrations added.

(51) 1913. Cardin, Patricio.

Note (supplementing Preliminary Report on the Enemies of Sugar-Cane in Cuba, by J. S. Houser). In Estación Experimental Agronómica de Cuba, Cir. 43, Santiago de las Vegas, 1913, pp. 24-29.

States (p. 29) that "el picudo" (Metamasius sericeus Oliv.) of the report is the same as that causing great damage in P. R. and Lesser Antilles.

(52) 1913. Crossman, S. S.

"La Changa", Scapteriscus didactylus. In Second Rept., Board of Comm. Agr. of P. R., 1912-1913, pp. 32-35.

Discusses control as a tobaceo pest.

(53) 1913. FeLt, E. P.

Three New Gall Midges (Diptera). In Canadian Entomologist, Vol. 45, No. 9, Sept. 1913, pp. 304-308.

Describes Karschomyia cocci n. sp. from Patillas, P. R., and Mycodiplosis insularis n. sp. from Río Piedras, P. R.; reared from mealy-bug on sugar cane and from red-spider.

(54) 1913. Hood, J. D.

Two New Thysanoptera from Porto Rico. In Insecutor Inscitice Menstruus, Vol. 1, No. 6, June 1913, pp. 65-70. pl. 1.

Describes Podothrips semiflavus n. sp. from Panicum barbinode and sugar cane at Guánica, P. R. 
(55) 1913. HoOKER, C. W.

Entomological Conferences in Porto Rico. In Jl. Econ. Ent., Vol. 6, No. 1, Feb. 1913, pp. 148-150.

Notes briefly papers on Maymbetles of P. R. (by

D. L. Van Dine), cane aphis (T. H. Jones), the changa

(S. S. Crossman), a fungus parasite of cane mealy-bug

(R. C. McConnie), and cane insect work at Guánica

(T. C. Murphy).

(56) 1913. Hooker, C. W.

Report of the Entomologist. In Ann. Rept., P. R. Agr. Exp. Sta. for 1912, Washington, July 26, 1913, pp. 34-38.

Discusses a Tachinid parasite (Cryptomeigenia sp.) of May-beetles (p. 35) and attempted use of the fungus, Metarrizium anisoplice, against May-beetles (pp. $36-37)$.

(57) 1913. Jomestron, J. R.

Report of the Pathologist. In 3d. Ann. Rept. (Bul. 5) of Exp. Sta. P. R. S. P. A., Río Piedras, Aug. 1913, pp. $22-24$.

Discusses use of Hawaiian beetle fungus against May-beetles (pp. 23-24), and of other fungi against cane pests.

(58) 1913. JoNEs, T. H.

Some Notes on Laphygma frugiperda S. \& A. in Porte

Rico. In Jl. Econ. Fnt., Vol. 6, No. 2, April, 1913, pp. 230-236.

Discusses this species and Remigia repanda Fab. as cane pests.

(59) 1913. Quaintance, A. L.

Remarks on Some of the Injurious Insects of Other Coun. tries. In Proc. Ent. Soc. Washington, Vol. 15, No. 2, June 10, 1913, pp. 54-83.

Mentions from P. R.: Scapteriscus didactylus Latr. (p. 57), Pseudococcus sacchari Clkll. (p. 63), and Lachnosterna spp. (pp. 76-77).

(60) 1913. Tower, W. V.

Rept. of the Entomologist's Inspection Trip to Santo Domingo. In 2nd. Rept., Board Comm. Agr. of P. R., 1912-1913, pp. 25-28.

Supposed identity of several Santo Domingo cane pests with those of Porto Rico.

(61) 1913. VAN DrNe, D. L.

The Insects Affecting Sugar Cane in Porto Rico. In Jl. Econ. Ent., Vol. 6, No. 2, April, 1913, pp. 251-257.

Resumé of all published information on cane insects of $P$. R. to that date, with discussion and original observations on each pest. 
(62) 1913. VAN DINE, D. L.

The Introduction of Parasites of May-beetles into Porto.

Rico. In Second Rept. Board Comm. Agr. of P. R. for 1912-1913, San Juan, June 30, 1913, pp. 36-48.

Introduction of Tiphia inornata cocoons from Illinois (including tables).

(63) 1913. VAN Dine, D. L.

Report of the Entomologist." In 3rd. Ann. Rept. Exp.

Sta., P. R. S. P. A., Río Piedras, Aug. 1913, pp. 25-46.

List and bibliography of sugar-cane pests in Porto Rico; also account of the rhinoceros beetle and the weevil root-borer.

(64) 1913. Van Dine, D. L.

Insects Injurious to Sugar-Cane in Porto Rico, and Their

Natural Enemies. In Jl. Board Agr., Brit. Guiana, Vol. 6, No. 4, pp. 199-203.

(65) 1913. WaLtoN, W. R.

New North American Tachinida (Diptera). In Entomological News, Vol. 24, No. 2, Feb., 1913, pp. 49-52, pl. 1.

Description of Eutrixoides jonesii gen. et sp. nov., from Porto Rico, reared from Lachnosterna (pp. 5051).

(66) 1913. Wolcott, George N.

Report on a Trip to Demerara, Trinidad and Barbados During the Winter of 1913. In 3d Ann. Rept. (Bul. 5), Exp. Sta. P. R. S. P. A., Río Piedras, Aug. 1913, pp. 47-68.

Compares cane pests of these countries with those of Porto Rico.

(67) 1913. Wolcott, George N.

Report on a Trip to Demerara, Trinidad and Barbados During the Winter of 1913. In Jl. Econ. Ent., Vol. 6, No. 6 (Dec. 1913), pp. 443-457.

Extract of the preceding article.

(68) 1913.

Useful Birds of Porto Rico. In Porto Rico Progress, Vol. 4, No. 13, pp. 13-14. (Noted from Experiment Station Record, Vol. 28, No. 8, June 1913, p. 751.)

Several species of herons found by Biological Survey to destroy changa.

(69) 1913.

Destruction of Mole Crickets in Porto Rico by the Heron and Gaulding. In The Agricultural News, Barbados, Sept. 27, 1913, p. 314. 1913.

Review of article in Exp. Sta. Record for June,

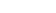


(70)

1913.

An Entomological Visit to the United States. In The Agricultural News, Barbados, Oct. 25, 1913, p. 346.

Includes visit to $P$. R. and brief discussion of cane pests of the Island.

(71) 1914. BAllou, H. A.

Insect Pests of Sugar Cane in Antigua and St. Kitts. Pamphlet Series No. 75, Imp. Dept. Agr. for W. 1., Barbados, 1914, pp. 45, pl. 1, figs. 20.

Notes Strategus titamus (p. 43) and Diaprepes spengleri (pp. 41-43) as occurring in P. R.

(72) 1914. Jones, T. H.

Sugar-Cane Insects in Porto Rico. In Jl. Econ. Fnt., Vol. 8, No. 6, Dee. 1914, pp. 461-463. (See Review Applied Ent., A, III, 3, March 1915, p. 134.)

Discusses known cane insect pests of the Island, including a number not before recorded (Pseudococcus calceolarice, Aphis setaria, Prenes ares, Tetranychus sp. and 2 species of thrips).

(73) 1914. Leng, Chas. W., and Mutchler, A. J.

A Preliminary List of the Coleoptera of the West Indies as Recorded to January 1, 1914. Bulletin of Am. Mus. Nat. Hist., Vol. 23, Art. 30, pp. 391-493, New York, Aug. 26, 1914.

Beetles known to attack cane listed from $P$. R. on pağes $442,454,469,478$ and 480 .

(74) 1914. PIERCE, W. DWIGHT.

Description of Two New Species of Strepsiptera (Halcotophagidæ) Parasitic on Sugar-Cane Insects. In Proc. Ent. Soc. Washington, XVI, 3, Sept. 1914, pp. 126-129.

Stenocranus saccharivorus parasitized by Stenocranophilus quadratus gen. et sp. nov. at Río Piedras, P. R., in Oct. 1912.

(75) 1914. VaN ZWaluwenburg, R. H.

Preliminary Check List of Porto Rican Insects, Mayagüez, Sept. 1914, pp. 62. (Additions to same, March 1915, pp. 15.)

Mimeographed list distributed to friends and museums. Cane pests listed, under orders.

(76) 1914. WALTON, W. R.

Four New Species of Tachinida from North America. In Proc. Ent. Soc. Washington, XVI, 2, pp. 93-95. Washington, June 1914.

Describes two from P. R., Linnemyia fulvicanda from Remigia repanda, and Compsilura oppugnator from Cirphis latiuscula.

(77) 1914. WoLCoTt, GeorGE N.

Notes on the Life-History and Ecology of Tiphia inornata 
Say. In Jl. Econ. Ent., Vol. 7, No. 5, Oct. 1914, pp 382-389.

Studies in connection with collection of cocoons for shipment to Porto Rico.

(78) 1914.

Termites or White Ants. In Agricultural News, Vol. 13; No. 309, Feb. 28, 1914, p. 74.

States that "the species of Eutermes are known to attack cane plants in the field in Antigua and Porte Rico," and lists $E$. acagutlas from P. R.

(79) 1915. BaLLOU, H. A.

Notes on Porto Rico Insects. In The Agr. News, Barbados, Aug. 28, 1915, p. 282.

Reviews Circular 6, P. R. Insular Exp. Sta., on "the changa".

(80) 1915. Crossman, S. S., and Wolcotro, G. N.

Control of the Changa. Cir. 6, Insular Exp. Sta. of P. R.

Río Piedras, 1915, pp. 3.

Recommends a bait of flour and Paris green.

(81) 1915. Fistre, R. J.

Report of the Quarantine Inspection Work. In 3d Rept., Board Comm., Agr. of P. R., 1913-1914, San Juan, 1915 pp. 14-19.

Mentions the fire ant (Solenopsis geminata) as "a very serious pest to the fruit, coffee, and sugar industry" (p. 19).

(82) 1915. Holloway, T. E.

Fighting the Sugar-Cane Borer with Parasites and Poisons. In The Louisiana Planter, Dec. 18, 1915, pp. 397398.

Discusses the effects of trash burning and of rain. fall on Diatrea in Porto Rico.

(85) 1915. JoHnston, J. R.

Report of the Work of the Department of Pathology. In 3d Report, Board Comm. Agr. of Porto Rico, 1913-1914, San Juan, 1915, pp. 63-64.

Notes an experiment in the use of Green Muscardine fungus to control May-beetles.

(84) 1915. JOHNSTON, JoHN R.

The Entomogenous Fungi of Porto Rico. Bul. 10, Board Comm. Agr. of P. R., Río Piedras, Mar. 15, 1915, pp. 33 , pls. 9.

Fungi attacking cane insects: Agrostalagmus albus (p. 10), Aspergillus flavus (pp. 14-18), Botrytis rileyi (pp. 18-19), Isaria barberi (pp. 20, 24-25), Empusa sphcerosperma (pp. 22-23), Isaria sp. (pp. 25-26), and Metarthizium anisoplio (pp. 26-28). 
(85) 1915. JONES, THOS. H.

Report of the Department of Entomology. In Third Report, Board Comm. Agr. of P. R., 1913-1914, San Juan, 1915, pp. 19-25.

Discusses work on May-beetles and their introduced parasites, and proposed work on other cane pests.

(86) 1915. JoNES, T. H.

Aphides or Plant Lice Attacking Sugar-Cane in Porto

Rico. Bul. 11, Exp. Sta. of Board Comm. Agr. of P. R., Mar. 15, 1915, pp. 19, pls. 2.

Life-history and habits of Sipha flava Forbes and Aplits setarice Thos.

(87) 1915. JoNES, T. H.

The Sugar-Cane Moth Stalk-Borer (Diatrcea saccharalis Fabr.). Bul. 12, Exp. Sta. of Board Comm. Agr. of

P. R., Río Piedras, Mar. 16, 1915, pp. 30, figs. 8. Life-history, parasites, control, ete.

(88) 1915. Jones, THOMAS H.

Insects affecting Vegetable Crops in Porto Rico. Bul. 192, U. S. D. A., Washington, Apr. 8, 1915, pp. 11, pls. 4.

Discusses Scapteriscus didactylus Latr. (p. 4), Diabrotica graminea Bal. (p. 5), Laphygma fungiperda S. \& A. (p. 7), and Solenopsis geminata Fab. (p. 9) as vegetable pests.

(89) 1915. Jones, THos. H.

The Sugar-Cane Weevil Root-Borer (Diaprepes spengleri

L.). Bul. 14, Exp. Sta., Board Comm. Agr. of P. R.,

Río Piedras, Apr. 14, 1915, pp. 19, figs. 11.

Life-history, habits, parasites, control, ete.

(90) 1915. Pmerce, W. DWight.

Some Sugar-Cane Root-Boring Weevils of the West Indies.

In Jl. Agr. Research, Vol. 4, No. 3, Washington, June 15,1915 , pp. 255-263, pls. 4.

Groups the forms of Diaprepes attacking sugar cane into 2 species, famelicus Oliv. and spengleri Linn., the latter of them having 6 varieties, 3 of which occur in Porto Rico. Gives briefly control measures.

(91) 1915. SMrTH, F. G.

Report of Work at the South Coast Laboratory. In $3 \mathrm{~d}$.

Report, Board Comm. Agr. of P. R., 1913-1914, San Juan, 1915, pp. 40-53.

Field habits and control of 3 species of Lachnosterna, 2 of Dyscinetus, 1 of Ligyrus and 1 of Strategus (cane pests), and release of Tiphia wasps from Illinois.

(92) 1915. TowER, W. V.

Report of the Secretary. In Third Report, Board Comm. Agr. of P. R., 1913-1914, San Juan, 1915, pp. 9-13. 
Notes work "combating the changa" (p. 10), and of the traveling entomologist "obtaining parasites of the white-grub, changa, mealy-bug and moth-borer", (p. 11).

(93) 1915. VAN Zwaluwenburg, R. H.

Report of the Entomologist. In Rept. P. R. Agr. Exp. Sta., U. S. D. A., for 1914, Mayagüez, July 10, 1915, pp. $31-35$.

Discusses control of Scapteriscus didactylus (pp. 31-32), of May-beetles by a bacterium (p. 34), and gives note on Diaprepes spengleri (p. 35).

(94) 1915. Wolcott, G. N.

Report of the Traveling Entomologist. In 3d. Rept., Board Comm. Agr. of P. R., 1913-1914, San Juan, 1915, pp. $25-40$.

Introduction of May-beetle parasites from Illinois and account of trips to Cuba and Jamaica to secure cane insect parasites.

(95) 1915. WolCotr, George N.

Influencia de la lluvia y la quemazón de la paja sobre la abundancia de Diatrcea saccharalis. Cir. 7, Insular Exp. Sta. of P. R., Río Piedras, 1915, pp. 6.

(96) 1916. Ballou, H. A.

Fighting the Sugar-Cane Borer with Parasites and Poisons. In The Agr. News, Barbados, Apr. 22, 1916, pp. 138-139.

Reviews article by Holloway in Louisiana Planter, Dec. 18, 1915. Mentions effects of rainfall on Diatræa in P. R.

(97) 1916. Marshald, G. A. K.

On New Neotropical Curculionidæ. In Ann. and Mag. Nat. Hist., Vol. 18, No. 108, London, Dec. 1916, pp. 449-468.

Diseusses the synonymy of species and varieties of Diaprepes characterized by Pierce (Jl. Agr. Research, June 15, 1915).

(98) 1916. MerriLL, G. B.

Report of the Tobacco Insect Investigations. In 4th Report, Board Comm. Agr. of P. R., 1914-1915, San Juan, 1916, pp. 50-52.

Discusses control of changa (pp. 50-51).

(99) 1916. Sммте, E. G.

Report of the South Coast Laboratory. In 4th Report, Board Comm. Agr. of P. R., 1914-1915, San Juan, 1916, pp. $45-50$.

Account of experimental work on white grubs, and table of life-history summaries of 8 species of Scarabæidæ, attacking cane. 
(100) 1916. Strevenson, JoHn A.

Report of the Pathologist. In 4th Report, Board Comm. Agr. of P. R., 1914-1915, San Juan, 1916, pp. 33-44.

Work with the Green Muscardine (pp. 34-35).

(101) 1916. Tlower, W. V.

Report of the Secretary and Director. In 4th Report, Board Comm. Agr. of P. R., 1914-1915, San Juan, 1916, pp. $9-16$.

Notes briefly (p. 11) the year's work on cane pests and changa.

(102) 1916. VAN ZWaLUWENBURG, R. H.

Report of the Entomologist. In Rept. P. R. Agr. Exp. Sta., U. S. D. A., for 1915, Mayagüez, Nov. 23, 1916, pp. $42-45$.

Discusses Scapteriscus didactylus (p. 42), Eutermes morio as a timber pest (p. 43), Strategus quadrifoveatus as a coconut pest (p. 44), Apate francisca as a. mahogany pest (p. 44), and Sipha flava on cane (p. 45).

(103) 1916. WetMore, Alex.

Birds of Porto Rico. Bul. 326, Bu. Biol. Sur., U. S. D. A., 1916, pp. 140, pls. 10. (= Bul. 15, P. R. Insular Exp. Sta.)

Gives stomach contents of majority of P. R. birds, enumerating cane pests.

(104) 1916. Wolcott, George N.

Report of the Fntomologist. In 4th Report, Board Comm. Agr. of P. R., 1914-1915, San Juan, 1916, pp. 17-22.

Gives summary of bulletins 11, 12 and 14, dealing with cane pests, by T. H. Jones.

(105) 1916 .

The Birds of Porto Rico. In the Agricultural News, Barbados, July 1, 1916, p. 219.

Review of Bulletin 326, U. S. D. A., by Alex Wetmore; discusses bird enemies of cane insects in P. R.

(106) 1917. Hutson, J. C.

Some Weevils of the genus Diaprepes in the West Indies. In The Agricultural News, Barbados, June 16, 1917, p. 186.

Gives table and distribution of species recently determined by Dr. Pierce.

(107) 1917. Huison, J. C.

White Grubs Injuring Sugar-Cane in Porto Rico. In The Agricultural News, Barbados, July 14 (pp. 218-219), July 28 (p. 234), and Aug. 11, 1917 (pp. 250-251).

Review and discussion of article of same title by Smyth in Jl. Dept. Agr. of P. R., Vol. 1, No. 2, pp. 47-92. 
(108) 1917. Hutson, J. C.

Sugar-Cane White Grubs in Porto Rico. In The Agricultural News, Barbados, Oct. 20, 1917, pp. 330-331.

Review and discussion of article on white-grubs by Smyth in Jour. Dept. Agr. of P. R., Vol. 1, No. 3, pp. 141-169.

(109) 1917. JONES, T. H.

A List of the Coccidie of Porto Rico. In Jl. of Board Comm. Agr. of P. R., Vol. 1, No. 1, Jan. 1917, pp. 1-16.

Lists Pseudococcus calceolarice Mask. (p. 4), Ps. sacchari Ckll. (p. 5), Aclerda tolionis Ckll. (p. 8) and Aspidiotus sacchari Ckll. (p. 12) as cane pests.

(110) 1917. Smyrt, E. G.

The White-Grubs Injuring Sugar-Cane in Porto Rico, Part

I, Melolonthids. In Jl. Dept. Agr. of P. R., Vol. 1, No. 2, Apr. 1917, pp. 47-92, pls. 8, and Vol. 1, No. 3, July 1917, pp. 141-169.

Researches into the life-history, damage, distribution, parasites, etc., of 4 new species of Phyllophaga (=Lachnosterna) and 1 new species of Phytahus.

(111) 1917. Sмчте, E. G.

The White-Grubs Injuring Cane and Other Crops in Porto

Rico. In Porto Rico Progress, San Juan, May 18, 1917. Popular account of their injuries and life-histories.

(112) 1917. Sмrтн, E. G.

Report of the Entomological Department. In Ann. Rept. Insular Exp. Sta. of P. R., 1916-1917, Río Piedras, 1917, pp. 99-106.

Account of cane insects intercepted from Santo Domingo, and of fumigation of cane steamers (pp. 105 106).

(113) 1917. Stevenson, J. A.

Report of the Pathologist. In 5th Report, Board Comm. Agr. of P. R., 1915-1916, San Juan, 1917, pp. 35-74.

States (p. 68) that moth stalk-borer larve pass through uninjured when cane trash is burned.

(114) 1917. Stevenson, John A.

Report of the Department of Pathology and Botany. In Ann. Rept., Insular Exp. Sta. of P. R., 1916-1917, Río Piedras, 1917, pp. 37-98.

Notes (p. 56) injury to cane experiments by Diatrea, Diaprepes spengleri and Phyllophaga spp.

(115) 1917. Tower, W. V.

Report of the Director. In 5th Report, Board Comm. Agr. of P. R., 1915-1916, San Juan, 1917, pp. 9-15.

Notes briefly work on Diatraa saccharalis (p. 14) and on changa (p. 15). 
(116) 1917. VAN Zwaluwenburg, R. H.

Insects Affecting Coffee in Porto Rico. In Jl. Econ. Ent, Vol. 10, No. 6, Dec. 1917, pp. 513-517.

Discusses: Apate fransisca Fab. (p. 516) and the May-beetles and their two Tachinid parasites ( $p$. 517 ).

(117) 1917. WoLCO'T, G. N

Report of the Entomologist. In 5th Report, Board Comm. Agr. of P. R., 1915-1916, San Juan, 1917, pp. 75-85, pl. 1.

Effect of rainfall and trash burning upon infestation of cane by Diatrcea saccharalis (pp. 80-85).

(118) 1918. Cotron, R. T.

Experimental Work on the Control of the White Grubs of Porto Rico. In Jl. Dept. Agr. of P. R., Vol. 2, No. 1, Jan. 1918, pp. 1-18.

Deals with the larve of Phyllophaga, mainly as sugar-cane pests. Summarizes work of other investigators.

(119) 1918. Cotron, R. T.

Medios para Combatir los Gusanos Blancos. Cir. 12, Insular Exp. Sta. of P. R., Río Piedras, 1918, pp. 7.

Control measures for white-grubs.

(120) 1918. Cotron, R. T.

Insects Attacking Vegetables in Porto Rico. In Jl. Dept. Agr. of P. R., Vol. 2, No. 3, Oct. 1918, pp. 265-317, figs. 67.

Discusses: Changa (p. 270), grasshoppers (p. 272), white-grubs (p. 274), Laphygma frugiperda (p. 288), Diatrea saccharalis (p. 290), fire ant (p. 296), and Diabrotica graminea (p. 302).

(121) 1918. Hutson, J. C.

The Production of Light in Certain Animals. In The Agricultural News, Barbados, Jan. 12, 1918, pp. 10-11. Mentions larvæ of Pyroplorus luminosus as predacious on white-grubs in cane fields in P. R.

(122) 1918. HuTson, J. C.

The West Indian Mole Cricket or Changa. In The Agricultural News, Barbados, Apr. 6, 1918 (pp. 106-107, fig. 1), and Apr. 20, 1918 (p. 122).

Review and discussion of Bil. 23, P. R. Agr. Exp. Sta., U. S. D. A.

(123) 1918. Stevenson, J. A.

The Green Muscardine Fungus in Porto Rico. In Jl. Dept. Agr. of P. R., Vol. 2, No. 1, Jan. 1918, pp. 19-32, pl. 1. Twenty-one out of 29 recorded insect hosts are cane pests.

(124) 1918. Stevenson, J. A.

A Check List of Porto Rican Fungi and a Host Index. In 
J1. Dept. Agr. of P. R., Vol. 2, No. 3, July 1918, pp. 125-264. 218.

Fungi attacking cane insects, pp. 134, 207, 208 and

(125) 1918. Van Zwahuwenisurg, R. H.

Report of the Entomologist. In Rept., P. R. Agr. Exp.

Sta., U. S. D. A., for 1916, Mayagüez, Feb. 5, 1918, pp. 25-28, pl. 1.

Discusses light trapping of May-beetles (pp. 25, 26), Scapteriscus vicinus (p. 25), and Sipha flava (p. 28 ). States that termite previously reported as Eutermes morio is Cryptotermes sp.

(126) 1918. VAN Zwalutwenburg, R. H.

The Changa or West Indian Mole Cricket. Bul. 23, P. R. Agr. Exp. Sta., U. S. D. A., Mayagüez, Feb. 12, 1918, pp. 28 , pls. 3.

Considered "the most serious insect pest of general agriculture in Porto Rico." Bibliography of 54 titles appended.

(127) 1918. Van Zwaluwenburg, R. H.

Some Means of Controlling Insects, Fungi, and Other Pests in Porto Rico. Cir. 17, P. R. Agr. Exp. Sta., U. S. D. A, Mayagüez, June 27, 1918, pp. 30.

Includes special control measures for cut-worms, changa, fire-ant, etc.

(128) 1918. Van Zwaluwenburg, R. H.

Report of the Entomologist. In Rept. P. R. Agr. Exp. Sta., U. S. D. A., for 1917, Mayagüez, Sept. 20, 1918, pp. 33-34.

Notes light trapping of changas, strategns quadrifoveatus as a coconut pest, and tests of cyanamid as remedy for white grubs (p. 34).

(129) 1919. Ballov, H. A.

The Toad in the West Indies. In The Agricultural News, Barbados, Nov. 29, 1919, pp. 378-379.

Diseusses the proposed introduction of toads into Porto Rico to combat white-grubs (see number 132, this list).

(130) 1919. Colón, E. D.

Report of the Director. In Ann. Rept., Insular Exp. Sta. of P. R. for June 30, 1918, Río Piedras, 1919, pp. 6-77.

Review of entomological work from 1913 to 1918 , pp. 8-13; 29-59. Cane pests, pp. 8, 29-30, 32-33, $37-58$.

(131) 1919. Holloway, T. E. and Loftin, U. C.

The Sugar-Cane Moth Borer. Bulletin No. 746, U. S.

D. A., Washington, Apr. 18, 1919, pp. 74, pls. 10, figs. 12. 
Mentions climatic and fungus control (pp. 35-38) and parasites (p. 41) of Diatraa in Porto Rico.

(132) 1919. Siryti, E. Graywood.

Report of the Division of Entomology. In Ann. Rept., Insular Exp. Sta. of P. R. for June 30, 1918, Río Piedras, 1919, pp. 109-129.

Insect transmission of cane mottling disease (pp. 118-119), cane white-grub problem (pp. 119-120), hard-backs injuring cane (pp. 120-121), red-spider attacking cane (pp. 121-122), epidemic of yellow cane aphis (pp. 122-123), and Eutermes morio (pp. 126127).

(133) 1919. Smythe, E. Graywood.

Report of the Entomologist. In Ann. Rept., Insular Exp. Sta. of P. R. for year ending June 30, 1919, Río Piedras, 1919, pp. 27-31.

Work on the transmission of the sugar-cane mottling disease by insects, pp. 28-30.

(134) 1919. SMYtH, E. GRAYwood.*

[Work of the] Division of Fntomology. In Report of the Commisioner of Agr. and Labor of P. R., Bureau of Insular Affairs, War Dept., Washington, 1919, pp. $685-713$.

Mentions Bothriocera sp. as feeding on cane (p. 695), and discusses successful transmission of the cane mottling disease (p. 699) by means of Stenocranus saccharivorus Westw. and Aclerda tolionis Ckll. (the latter being a misdetermination for Pulvinaria iceryi Guer.).

(135) 1919 .

Entomology in Porto Rico. In The Agricultural News, Barbados, Nor. 15, 1919, pp. 362-363.

Review of the entomologist's report (Ann. Rept. P. R. Insular Exp. Sta.) for year ending June 30, 1918.

(136) 1919.

Skunks and Toads-A Warning. In The Agricultural News, Barbados, Nov. 15, 1919, p. 361.

Discussion of proposed introduction of skunks and toads into P. R. to combat white-grubs.

* The following paragraphs of this report: Plant Quarantine (pp. 691-692), Division of Entomology (p. 694), Work on Citrus Insect Pests (p. 695), and Entomological Work (on Yellow-Stripe Disenses) (p. 699), though not credited to the writer, : tre taken verbatim from his annual report, and were unfortunately omitted from the Annual heport of the Experiment Station for the same year. 